専門医症例報告

骨格性下顎前突を伴った Eichner C2 症例（上顎無歯顎）に対する補経治療

荻野 洋一郎

\title{
A Prosthetic Treatment for an Eichner C2 Patient with Skeletal Mandibular Prognathism
}

\author{
Yoichiro Ogino
}

抄 録

症例の概要：患者は 54 歳の女性。下顎前歯の舌側傾斜による発音障害と上顎全部床義歯の維持不良と審 美障害を主訴に来院した. 本初診以前に本院矯正歯科で骨格性下顎前突症の診断がなされていた。治療は, 下顎前歯の傾斜, 形態を審美, 発音の観点から設定後, 上顎前歯の位置, 咬合平面の設定を行った。 下顎 は歯の傾斜から前歯部と兒歯部に分けて陶材焼付鋳造冠による固定性橋義歯を作製した。

考察 : 複雑な問題を有する本症例では機能性，審美性の回復に綿密な治療計画の立案と治療用義歯，プロ ビジョナルレストレーションが必須であった。

結論：綿密な治療計画の立案によって骨格性下顎前突を伴った Eichner C2 症例における機能性，審美性 の回復が可能となった。

和文キーワード

骨格性下顎前突，Eichner C2，上顎無歯顎，シングルデンチャー

\section{ABSTRACT}

Patient: A 54-year-old woman presented with a chief complaint of disorder of articulation caused by lingual-inclined mandibular anterior teeth, poor retention of complete denture in the maxilla, and esthetic problems. Her ailment had been diagnosed as skeletal mandibular prognathism before she presented. The position of the mandibular anterior teeth were set up according to esthetic and phonetic aspects, followed by setups of the positions of anterior maxillary teeth and occlusal plane. Porcelainfused-to-metal fixed partial dentures were fabricated in the anterior and posterior areas in the mandible.

Discussion: This case required sufficient exploration, well-considered treatment planning and procedures with a treatment denture, and provisional restorations to enable rehabilitation from the complicated functional and esthetic problems.

Conclusion: According to the considered treatment planning, both the functions and the esthetics could be rehabilitated in an Eicher C2 patient with skeletal mandibular prognathism.

\section{Key words}

skeletal mandibular prognathism, Eichner C2, edentulous maxilla, single denture

九州大学大学院歯学研究院口腔機能修復学講座インプラント・義歯補綴学分野

Section of Implant and Rehabilitative Dentistry, Division of Oral Rehabilitation, Faculty of Dental Science, Kyushu University

受付: 2012 年 6 月 25 日/受理 : 2012 年 11 月 12 日

Received on June 25, 2012/Accepted on November 12, 2012 


\section{I 。緒言}

上顎が無歯顎の Eichner C2 症例は下顎無歯顎の場合 と比べて比較的経過は良好に行くことが多いが, combination syndrome のような病態を呈する場合は義歯の 安定までに時間を要することが多い，本症例では，骨格 性下顎前突を伴った Eichner C2 症例（上顎無歯顎）に 対して機能性，審美性を考慮した治療を行ったので報告 する.

\section{II. 症例の概要}

患者：初診時年齢 54 歳，女性.

初診日：2005 年 11 月 24 日.

主訴：下の歯が中に入り込んでしゃべりにくく，上の 義歯も落ちやすい. 見た目が悪いので何とかしてほし い.

既往歴：20 代に虫垂炎.

現病歴 :

・1998 年＼cjkstart歯並びの悪さを主訴に九州大学歯学部附属 病院矯正歯科を受診。骨格性下顎前突と診断されるも治 療せず（図 1)。

・2000 年 近医 A 歯科医院にて歯周治療，カリエス 治療により，上下顎部分無歯顎となる。

•2004 年上下顎の補緅処置を自費で行う [上顎：陶 材燒付鋳造冠（以下，PFM）および金属床部分床義歯, 下顎 : PFM の固定性橋義歯（以下，FPD)].

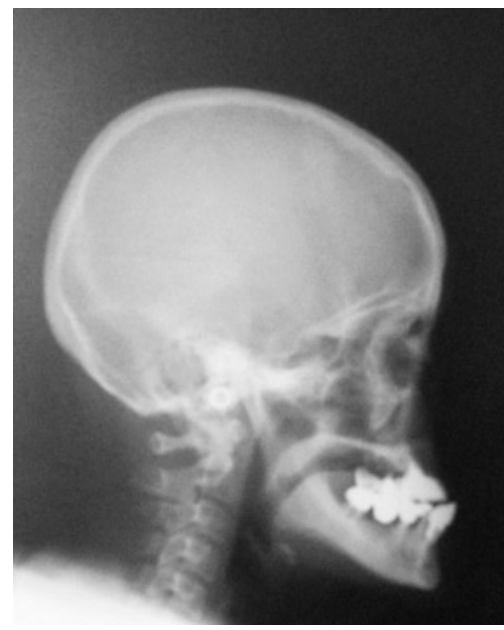

図 1 Cephalometric radiogram at Department of Orthodontics in 1998

1998 年当時の本院矯正歯科での頭部 X 線規格写真 (セファログラム)
・ 2005 年 8 月 同歯科医院にて上顎左側の残存歯を抜 去し，上顎は無歯顎となる。2004 年に作製した自費の 金属床を修理し，使用するが維持不良，審美的にも不満 を覚える，下顎の歯の位置も悪いといわれ，PFM を除 去し，テンポラリーブリッジを作製したところ，発音が 困難になった（舌側に傾斜させたため）.

・2005 年 9 月 近医 B 歯科医院にてインプラント治 療について相談。外科矯正も含女高額な治療費や今後の 治療計画に対して不安を感じる。

・2005 年 11 月 九州大学病院初診に至る.

現症：

1）全身所見：身長 $156 \mathrm{~cm}$ ，体重 $51 \mathrm{~kg}$ ，その他, 特記事項なし。

2）口腔内所見 : 初診時口腔内写真（義歯あり，義歯 なし)を図 2 に示す．上顎は，無歯顎で，下顎は 6(5)(4) (3) 2 1|lll2 1 (3) (4)(5)6 (7) となるようテンポラリーブリ ッジが装着されていた，上顎前歯相当部の粘膜は顕著な フラビーガムとなっており，上顎義歯の沈下を認めた。 上顎義歯は粘膜調整材によって裏装がなされており，重 量も大きかった。下顎残存歯は，下顎前突に伴った歯の 位置の修正のため，唇（煩）側が切削されており，全体 的に舌側傾斜した状態を呈していた。歯周組織は安定し ており，歯の動摇は認められなかった。

検査結果 : 下顎残存歯のデンタル X 線写真を図 3 に 示す．全顎的に水平性骨吸収を認めるものの，歯周組織 検査では全て $4 \mathrm{~mm}$ 以下であった。 54 には歯根に対 して太いメタルコアが装着されているが，歯根破折など の異常所見は認めなかった。

診断：上顎義歯不適合による咀嚼障害，審美障害。骨 格性下顎前突，上顎骨萎縮による発音障害，審美障害。
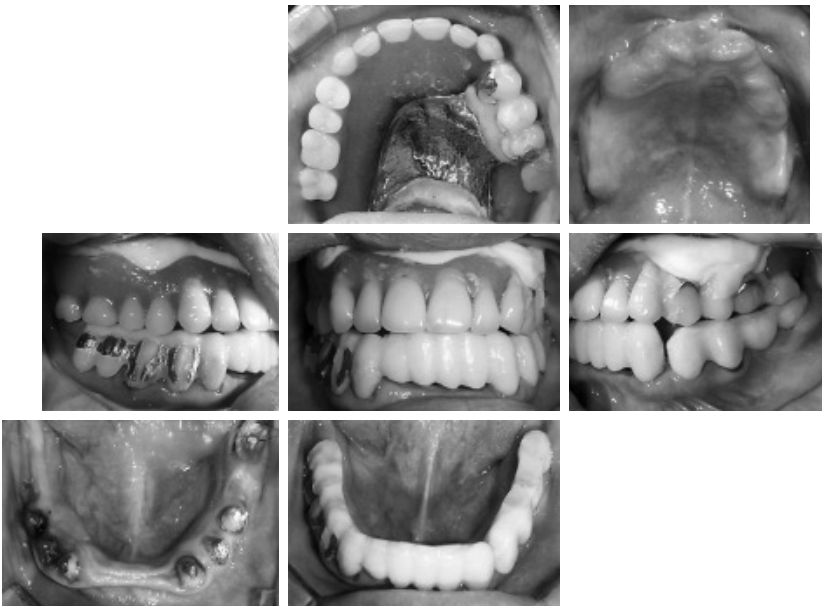

図 2 Intraoral views at first examination 初診時の口腔内写真 

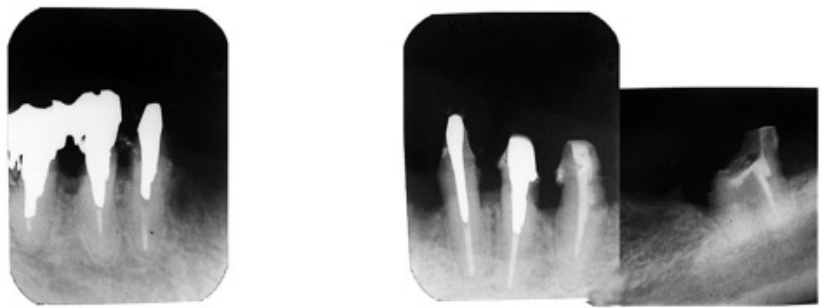

図 3 Radiographs at first examination 初診時のデンタル X 線写真

\section{III. 治療内容と経過}

\section{1. 治療方針および計画}

治療に先立ち，インフォームドコンセントを行った。 患者は当初はインプラント治療を考えていたが，まずは 上顎義歯の安定と審美障害の改善を図るために，治療用 義歯を作製すること，現在の発音障害が下顎のテンポラ リーブリッジの傾斜に起因している可能性を説明し，最 終的な歯冠形態(位置, 傾斜も含む)を模索したうえで, インプラントや他の欠損補綴の治療について考慮，計画 することを説明，了承を得た。

\section{2. 処置内容}

初診時の上顎の義歯の後縁の延長と粘膜調整材の使 用，咬合調整により上顎義歯の吸着は改善できた。その 後, 患者の審美的な要求に沿って上顎切歯の位置を設定 した上顎の全部床義歯（レジン床，治療用義歯）を作製 した。 その後，上顎義歯に合わせて下顎のテンポラリー ブリッジを修正（唇側へ傾斜）し，発音障害がどこまで 改善可能か，経過を観察した。特に下顎前歯の舌側の位 置，形態について調整を行い，患者の満足度を得られた 位置で最終的なプロビジョナルレストレーションを作 製，さらに調整を行った，前歯部は被蓋を与えず，臼歯 部は交叉咬合とした（図 4)。最終補綴の作製に際し， 上顎は通法に従い，ボーダーモールディングを行った後 に，フラビーガム部の可及的な無圧印象を行うために個 人トレーに遁路を付与し，そこからフローのよい印象材 を流し込み，印象採得を行った。下顎前歯の印象に先立 ち，上顎前歯の位置ならびに咬合平面を決定，下顎前歯 のプロビジョナルレストレーションの舌側の位置を変え ないよう注意し, 上顎の最終義歯, 下顎前歯部の PFM-

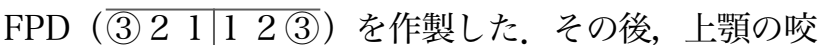
合平面に合わせて毛歯部の PFM-FPD (6 (5)(4) (4)(5) 6 (7) ) を作製した (2007 年 12 月，図 5)。なお, 咬合高径や被蓋の程度はプロビジョナルレストレーショ
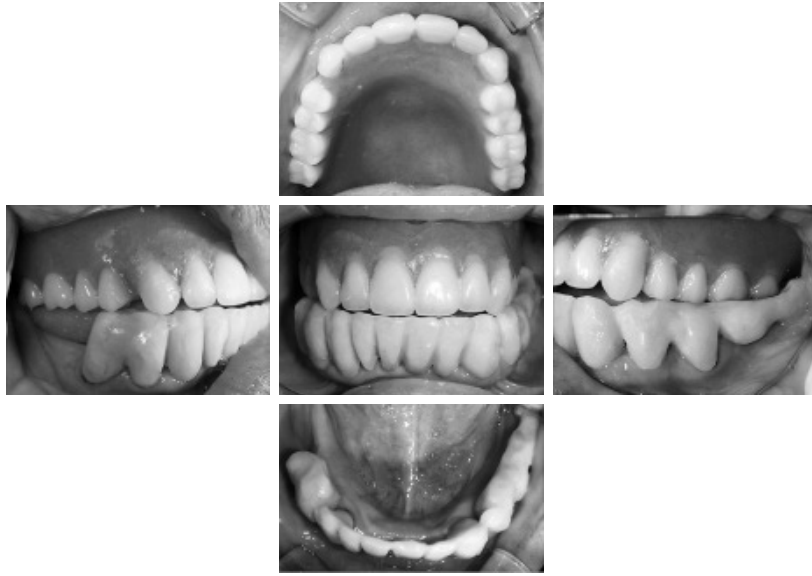

図 4 Intraoral views before final restoration 最終補綴処置前の口腔内写真

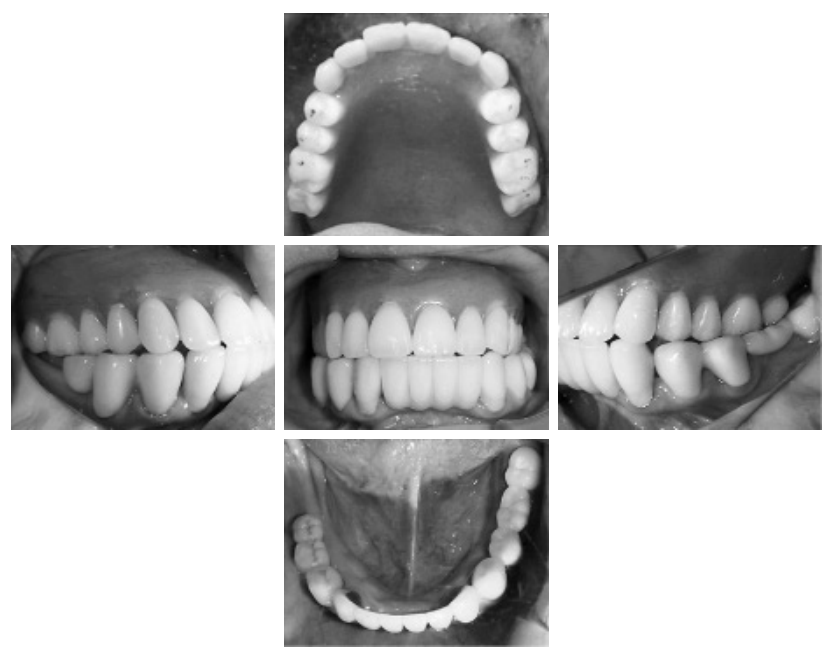

図 5 Intraoral views at final restoration 最終補経時の口腔内写真

ンを参考に設定した，下㖽右側第一大臼歯の延長ブリッ ジの咬合接触は中心咬合位で咬合紙が抜けるように調整 し，咬合を補うのではなく，食片の㚘側への移動を防ぐ 目的で設定した。本設計に関し，延長ブリッジの適応と リスク ${ }^{1)}$ を説明後, プロビジョナルレストレーション でも特に問題がなかったこと，患者が臼歯部への可撤性 義歯，インプラントでの補経処置を希望しなかったため に本設計を選択した。

\section{3. 術後の経過}

最終補経後も定期的なメンテナンスを行った（当院歯 周病科と併科)。最終補経終了後, 順調に経過していた が， 7 カ月後に「前歯で噛むと一時的に痛みが出た」と の訴えがあったが，臨床症状はなく，経過観察とした。 しかし，その 2 カ月後に， 34 間の隣接コンタクトの 


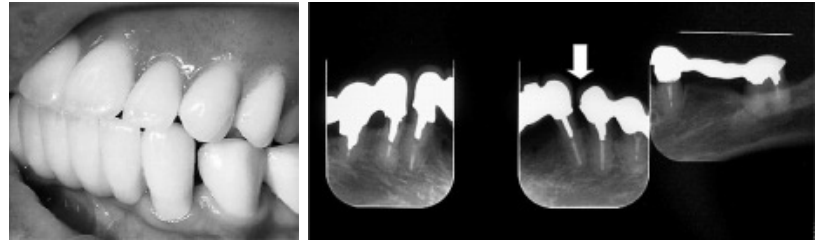

図 6 Intraoral view and radiographs of loss of the interproximal contact

コンタクト離解時の口腔内写真とデンタル X 線写真

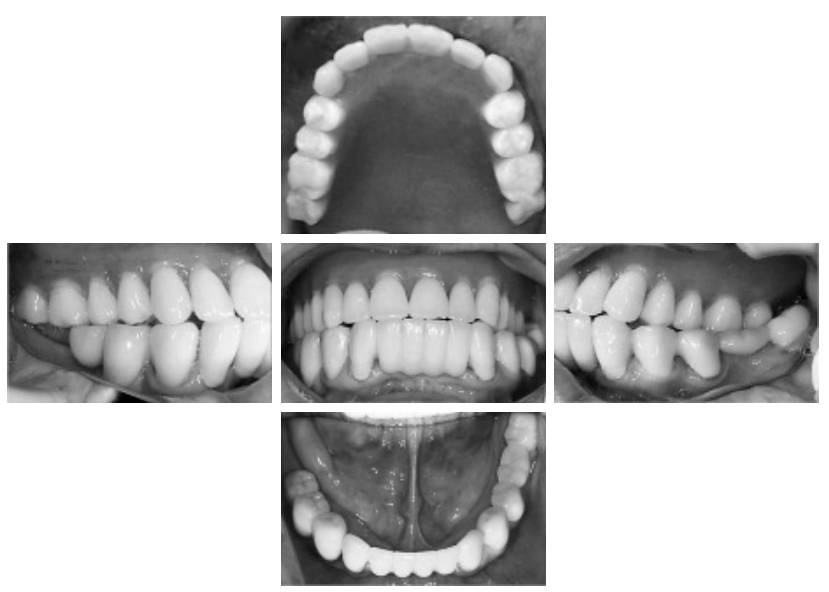

図 7 Intraoral views 3 years after final restoration 最終補経終了後 3 年後の口腔内写真

離開が認められたため，デンタル X 線写真や歯周組織 検査，動摇度の診査を行ったところ，特に異常所見は認 めなかったので，再度経過観察とした（図 6)。なお， 隣接コンタクトは審美的理由からリペアキットを用いて コンタクトの回復を行った。その後は良好に経過してい る(図 7).

\section{4. 術後の機能評価}

佐藤らの咀嚼スコアでは 65/100 のスコアを得てお り，審美，発音に関しては主観評価であるものの，患者 の満足は得られており，現段階では問題なく経過してい る.

\section{IV. 考察}

骨格性下顎前突の Eichner C2 症例（上顎無歯顎）の 本症例において，上顎シングルデンチャーによって生じ た前歯相当部のフラビーガムと上顎骨萎縮が治療を困難 にしていた ${ }^{2,3)}$. 被蓋改善のために上㖽前歯の位置を前 方に設定することはリップサポートか強くなりすぎるた めに審美的な問題を生じ，下顎前歯の舌側傾斜は発音障 害を引き起こしていた。 そこで，下顎前歯が発音の障害 とならない位置をプロビジョナルレストレーションを用 いることにより設定し，それに応じて上顎前歯の位置， 咬合平面の設定を行った。このように本症例では，治療 用義歯とプロビジョナルレストレーションによる問題解 決への確認の過程が必須であったと考えられた。最終補 綴後にコンタクトの離開という問題が起き，現在は特に 支障はないために，経過観察としているものの，今後の 咬合管理も必要だと思われる。

\section{V. 結 論}

骨格性下顎前突の Eichner C2 症例（上顎無歯顎）の 症例において，治療用義歯とプロビジョナルレストレー ションを用いることによって患者の抱える問題の解決が 可能かどうか確認を行い，それに応じて最終補綴を行っ たことで，良好な結果を得ることができた。

\section{文献}

1) Hill EE. Decision-making for treatment planning a cantilevered fixed partial denture. Compend Contin Educ Dent 2009; 30:580-585.

2) Kelly E. Changes caused by a mandibular removable partial denture opposing a maxillary complete denture. J Prosthet Dent 1972; 27: 140-150.

3) Carlsson GE. Responses of jawbone to pressure. Gerodontology 2004; 21:65-70.

著者連絡先: 荻野 洋一郎

T812-8582 福岡県福岡市東区馬出 3-1-1

Tel: 092-642-6441

FAX: 092-642-6380

E-mail:ogino@dent.kyushu-u.ac.jp 